\title{
Prevalence, geographical distribution and host specificity of parasitic copepode Lophoura szidati Stadler, 1978 (Copepoda: Sphyriidae) on grenadiers (Macrourus spp.) in the Antarctic
}

\begin{abstract}
I.I. Gordeev
Russian Federal Research Institute of Fisheries and Oceanography (VNIRO), Verkhnaya Krasnoselskaya Str. 17, Moscow 107140, Russia.

E-mail: gordeev@vniro.ru

ABSTRACT: A total of 5948 specimens of Macrourus whitsoni Regan, 1913, 142 M. holotrachys Günther, 1878 and also three M. caml McMillan, Iwamoto, Stewart et Smith, 2012 from Antarctic deep waters were examined for the presence of a mesoparasite, Lophoura szidati Stadler, 1978. All specimens were collected during four Antarctic summers (December-March) in seasons 2010-2013 and 2014-2015 as by-catch during fishing for Antarctic toothfish Dissostichus mawsoni Norman, 1937 at a depth from 586 to $2300 \mathrm{~m}$ in the Pacific, Indian and Atlantic sectors of the Antarctic. Considering that seasonal variability in the prevalence of parasites may be caused by differences in selectivity and efficiency of fishing gears, it can be concluded that upon circumpolar distribution of $L$. szidati its mean prevalence on $M$. whitsoni reaches $10-12 \%$ and higher in the Pacific sector of the Antarctic. M. caml is recorded as a host of $L$. szidati for the first time.

How to cite this article: Gordeev I.I 2015. Prevalence, geographical distribution and host specificity of parasitic copepode Lophoura szidati Stadler, 1978 (Copepoda: Sphyriidae) on grenadiers (Macrourus spp.) in the Antarctic // Invert. Zool. Vol.12. No.2. P.207-212. doi: 10.15298/invertzool.12.2.06
\end{abstract}

KEY WORDS: Lophoura szidati, Macrourus whitsoni, Antarctic.

\section{Встречаемость, географическое распространение и гостальность Lophoura szidati Stadler, 1978 (Copepoda: Sphyriidae) на макрурусах в Антарктике}

\section{И.И. Гордеев}

Всероссийский институт рыбного хозяйства и океанографии (ВНИРО), ул. Верхняя Красносельская 17, Москва 107140, Россия.

E-mail: gordeev@vniro.ru

РЕЗЮМЕ: Проанализировано 5948 особей Macrourus whitsoni Regan, 1913, 142 особи M. holotrachys Gьnther, 1878 и три особи M. caml McMillan, Iwamoto, Stewart et Smith, 2012 из Антарктических вод на предмет зараженности мезопаразитом Lophoura szidati Stadler, 1978. Все особи были пойманы в течение четырех промысловых сезонов (декабрь-март) с 2010 по 2013 г. и в 2014-2015 гг. при промысле Антарктического клыкача Dissostichus mawsoni Norman, 1937 на глубине от 586 до 2300 м в тихоокеанском, атлантическом и индоокеанском секторах Антарктики. Учитывая 
межсезонную вариабельность экстенсивности заражения и возможное влияние селективности и уловистости примеряемых орудий лова, можно заключить, что при циркумполярном распространении L. szidati экстенсивность заражения этим паразитом M. whitsoni в среднем по Антарктике достигает 10-12\% и несколько выше в тихоокенском секторе. M. caml описан как хозяин L. szidati впервые.

Как цитировать эту статью: Gordeev I.I. 2015. Prevalence, geographical distribution and host specificity of parasitic copepode Lophoura szidati Stadler, 1978 (Copepoda: Sphyriidae) on grenadiers (Macrourus spp.) in the Antarctic// Invert. Zool. Vol.12. No.2. P207-212. doi: 10.15298/invertzool.12.2.06

КЛЮЧЕВЫЕ СЛОВА: Lophoura szidati, Macrourus whitsoni, Антарктика.

\section{Introduction}

Due to remoteness and hindered accessibility of the most part of Antarctic waters, knowledge about deep-water fish parasites is scarce. Most studies in the Southern Ocean deal with taxonomy of fish parasites, and there are a few new studies on distribution and host-specificity of known species (Walter et al., 2002, Klimpel et al., 2010, Brown et al., 2013, Sokolov, Gordeev, 2013, 2015). L. szidati is one of the most common mesoparasites of Macrourus spp. previously recorded in the Atlantic sector of the Antarctic and sub-Antarctic (Stadler, 1978, Walter et al., 2002). Surprisingly, these two papers seem to be the only papers on $L$ szidati. Overall, 19 species of Lophoura are known, but only L. szidati is found in the Antarctic (Walter, Boxshall, 2015). Its site of infection is located near the base of the dorsal fin, with the outgrowth of the copepod neck reaching the body cavity throughout the body musculature. Life cycle of $L$. szidati is not known.

Macrourus spp. are very widespread deepwater fishes that inhabit depths from 400 to 3185 m (Cohen et al., 1990; Gon and Heemstra, 1990) and form one of the most important part of the bottom ecosystem's food chain. Along with other species $M$. whitsoni is one of the most common fish in the Antarctic. Its distribution is circumpolar and includes areas of continental slope and ocean depths. Up to 2012 only three species of grenadiers were known in the Antarctic - Macrourus whitsoni Regan, 1913, M. holotrachys Günther, 1876 and M. carinatus
Günther, 1878 in sub-Antarctic (Gon, Heemstra, 1990; Miller, 1993; Smith et al., 2011). But in 2012 the fourth species, M. caml McMillan, Iwamoto, Stewart et Smith, 2012 was described based on morphological and molecular data. Its distribution is widespread in the Southern Ocean including the Ross Sea, Balleny and Scott Islands slope, Cosmonaut Sea, south of South Georgia, at350-2080 m(McMillan et al., 2012).

The present study was carried out to consolidate data on infestation of the Antarctic Macrourus species by $L$. szidati collected during the four fishing seasons 2010-2013, 2014-2015 and, taking into account reference data, to summarize the existing knowledge about distribution, local variations of infestation prevalence and host-specificity of this species.

\section{Materials and methods}

All examined specimens of Whitson's grenadier (Macrourus whitsoni) were collected in the Antarctic in seasons 2010-2013 and 20142015 (February-March) during commercial and research fishing for toothfish Dissostichus sp. at a depth from 586 to $2300 \mathrm{~m}$ using bottom longline system of autoline and trot-line type [see Petrov et al. (2014) for the detailed descriptions of the fishing gear]. The total of 5948 specimens of $M$. whitsoni (TL 26-90 cm; anus length 10-31 cm; weight 130-3780 g) were examined. Locations of catch and quantitative characteristics of hauls are given in Tab. 1 and shown in Fig. 1. Prevalence of infestation (percentage of infested specimens), mean intensity 
Parasitic copepode Lophoura szidati on grenadiers (Macrourus spp.) in the Antarctic 209

Table Macrourus whitsoni localities of catch, sample size and indices of infestation by copepod Lophoura szidati in the Antarctic.

Таблица 1. Места вылова и размер выборки Macrourus whitsoni, индексы зараженности копеподой Lophoura szidati в Антарктике.

\begin{tabular}{|c|c|c|c|c|c|c|}
\hline \multicolumn{3}{|c|}{ Locality } & Season & Number & $\begin{array}{c}\text { Mean } \\
\text { Intensity } \\
\text { (Intensitv) }\end{array}$ & $\begin{array}{c}\text { Prevalence } \\
(\%)\end{array}$ \\
\hline \multirow{8}{*}{ 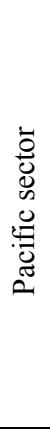 } & \multirow{3}{*}{$\begin{array}{c}\text { northern Ross } \\
\text { sea }\end{array}$} & \multirow{3}{*}{$65^{\circ} \mathrm{S} 178^{\circ} \mathrm{W}$} & 2010-2011 & 4 & $1.00(1)$ & 25.0 \\
\hline & & & $2011-2012$ & 15 & $1.00(1)$ & 20.0 \\
\hline & & & $2014-2015$ & 134 & $1.00(1)$ & 18.7 \\
\hline & \multirow{3}{*}{$\begin{array}{l}\text { Ross Sea } \\
\text { slope }\end{array}$} & \multirow{3}{*}{$\begin{array}{c}70-75^{\circ} \mathrm{S} \\
170^{\circ} \mathrm{E}- \\
174^{\circ} \mathrm{W}\end{array}$} & $2011-2012$ & 701 & $1.28(1-5)$ & 12.3 \\
\hline & & & $2012-2013$ & 1721 & $1.17(1-4)$ & 13.4 \\
\hline & & & 2014-2015 & 1431 & $1.26(1-5)$ & 10.1 \\
\hline & \multirow{2}{*}{$\begin{array}{l}\text { Amundsen } \\
\text { Sea }\end{array}$} & \multirow{2}{*}{$\begin{array}{c}69^{\circ} \mathrm{S} 126^{\circ} \mathrm{W} ; \\
71-73^{\circ} \mathrm{S} 118- \\
121^{\circ} \mathrm{W} \\
\end{array}$} & 2012-2013 & 110 & $1.24(1-3)$ & 15.5 \\
\hline & & & 2014-2015 & 390 & $1.15(1-2)$ & 8.7 \\
\hline \multirow{3}{*}{ 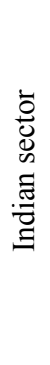 } & d'Urville Sea & $\begin{array}{c}64-65^{\circ} \mathrm{S} 130- \\
135^{\circ} \mathrm{E} ; 64- \\
65^{\circ} \mathrm{S} 139^{\circ} \mathrm{E}\end{array}$ & 2010-2011 & 177 & $1.11(1-3)$ & 10.7 \\
\hline & Mawson Sea & $\begin{array}{c}64-65^{\circ} \mathrm{S} ; \\
110-115^{\circ} \mathrm{E}\end{array}$ & 2010-2011 & 48 & $1.75(1-3)$ & 8.3 \\
\hline & $\begin{array}{l}\text { Cooperation } \\
\text { Sea }\end{array}$ & $66^{\circ} \mathrm{S} 70-75^{\circ} \mathrm{E}$ & 2010-2011 & 18 & $1.00(1)$ & 11.1 \\
\hline \multirow{2}{*}{ 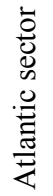 } & Weddell Sea & $\begin{array}{c}73-74^{\circ} \mathrm{S} 29- \\
32^{\circ} \mathrm{W}\end{array}$ & 2012-2013 & 1181 & $1.09(1-3)$ & 12.0 \\
\hline & $\begin{array}{l}\text { Bouvet Island } \\
\text { area }\end{array}$ & $\begin{array}{c}53-54^{\circ} \mathrm{S} 3- \\
4^{\circ} \mathrm{E}\end{array}$ & 2010-2011 & 18 & $1.00(1)$ & 11.1 \\
\hline
\end{tabular}

(the ratio of the number of parasites to the number of infested hosts) and extreme values of intensity were used as parasitological indices.

Three examined specimens of Macrourus caml (TL 42-45 cm; anus length 14-15 cm; weight 340-490 g) were caught in January 2015 in the following coordinates $-75^{\circ} 56^{\prime} \mathrm{S} ; 170^{\circ}$ $49^{\prime} \mathrm{W}$ (Ross Sea) at a depth of $965 \mathrm{~m}$. Species identification was done using McMillan et al. (2012). 142 specimens of M. holotrachys (TL 41-82 cm; anus length 15-29 cm; weight 300$2640 \mathrm{~g})$ were caught in the Scotia Sea $\left(53^{\circ} \mathrm{S}\right.$; $50^{\circ} \mathrm{W}$ ) in March 2013 at a depth of $925-1536 \mathrm{~m}$. Examination of infestation by $L$. szidati is very convenient due to large size of this mesoparasite and abundance of Macrourus sp. in by-catch during longline fishing for toothfish in all areas of the Antarctic. Examination does not require full dissection, and visual inspection with partial dissection is usually enough for evaluation of infestation prevalence and intensity.

\section{Results}

Mean prevalence on Macrourus whitsoni is pretty stable among seasons and samples and reached $10-12 \%$. Only one of three examined specimens of $M$. caml were infested. As on $M$. whitsoni the site of infection was near the base of the dorsal fin, with the outgrowth of the 


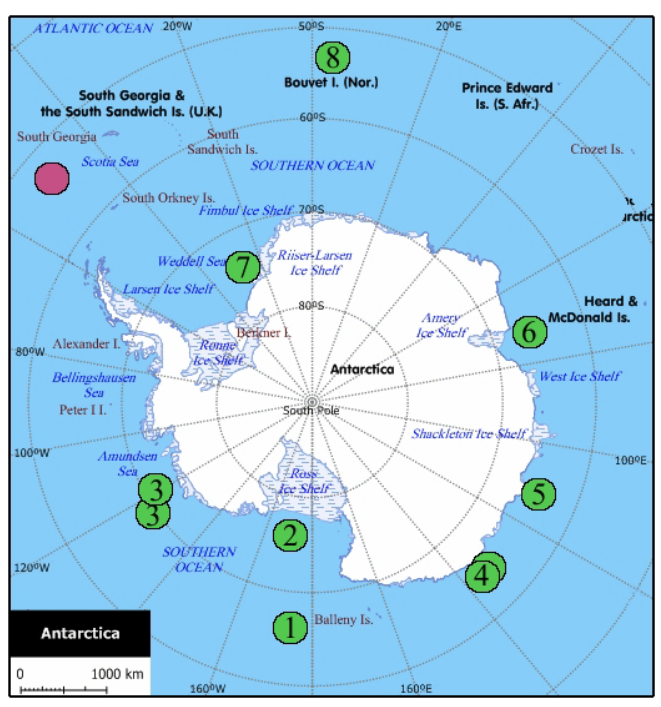

Figure 1. Map of the locations where the material was collected. The numbers indicating locations correspond to those in Table 1. Unnumeberd circle shows the location where Macrourus holotrachys was caught in season 2012/13 in the Scotia Sea.

Рисунок 1. Карта сбора материала. Номера локаций соответствуют номерам в Таблице 1 . Место вылова Macrourus holotrachys в сезоне 20122013 гг. в море Скоша отмечено ненумерованным кружком.

copepod neck reaching the body cavity throughout the body musculature. None of the examined specimens of Macrourus holotrachys was infested (Table 1).

Seasonal prevalence of $M$. whitsoni at the separately located seamounts at northern Ross Sea is higher than at the near-continental area. At the same time mean prevalence in the Pacific sector could be about half higher than in the other sectors of Antarctic. Most specimens of Whitson's grenadier carried only one individual of L. szidati, meanwhile the maximal intensity was found at the Ross Sea slope where number of them reaches five. In the cases of multiple infestation parasites could be located both on one spot and at the different sides of the body. Most parasites were found on small and middle size fishes (TL 16-48 cm) while large specimens found only a few cases of infestation. Pathogenicity is expressed in often inflamma- tion around the site of a parasite insertion into the host tissue and in damage to the muscle tissue, the wall of the body cavity and liver at the site of its joint intergrowths with copepode's holdfast.

Correlation between depth and prevalence or intensity was insignificant with no clear trend [correlation coefficient $r(p)=0.6102(0.0267)]$. The deepest place where infected $M$. whitsoni was caught is at the Mawson Sea $(2300 \mathrm{~m})$.

\section{Discussion}

Antarctic ecosystem is very famous for its homogenies when some species are endemic for the Antarctic and at the same time are found in all sectors, like Euphasia superba (Sala et al., 2002; Siegel et al., 2013), Dissostichus mawsoni (Mugue et al., 2014), Pleuragramma antarcticum, Bathydraco scotiae, Gerlachea australis (Miller, 1993; Shust, 1998). Despite circumpolar distribution (Fig. 1) of L. szidati in the Antarctic, which covers not only margins of shelf and continental slope but separately located seamounts in proximity to sub-Antarctic, our results show that in the Pacific sector its frequency of occurrence could be up to $50 \%$ higher than in other sectors of the Antarctic. More likely it is related with size of its host's biomass in the Ross Sea. Data on the larval stages are not available. We assume that the Ross Sea circulation current, described in the area between continental shelf and the Pacific-Antarctic Ridge (Rintoul, 2001), allows the infestation as the larvae remain within this current system. On one hand it also can explain higher maximal intensity (see Table 1) in the Ross Sea, — when most larvae are distributed within some boundaries a single host has higher chances to be infested. On the other hand, it may be caused by larger sample at the Ross Sea where a total of 3853 specimens were examined from slope when in other sectors there were substantially fewer specimens.

In Walter et al. (2002) there are data on infestation of $M$. whitsoni in the eastern Weddell Sea shelf $(n=65$, prevalence - $9 \%$, intensity -1 , mean int. 1) and near the South Shetland Islands $(\mathrm{n}=321$, prev. $-7 \%$, int. $-1-2$, mean 
int. - 1) which seems to be the last published information about the L. szidati. With a much smaller sampling these data harmonize with the data obtained by us.

The level of host specificity in copepods ranges through a continuum from high, with the parasite species occurring on only a single host species, to low, with the parasite species occurring on a wide range of phylogenetically unrelated hosts (Boxshall, 1998). The author also noted that in the deep sea where densities of potential hosts are relatively low and the presumed probabilities of the infective stage of the parasite encountering a suitable host are also low, parasites should be less host specific than in shallower waters where host densities are higher, on the assumption that any host is better than no host (Boxshall, 1998). There are no new records that $L$. szidati has lower host specificity than its congener species and parasitize on representatives of other deep-water fish genera in the Antarctic other than Macrourus. Other representatives of fam. Sphyriidae like Sphyrion lumpi show much lower level of host specificity parasitizing on at least 19 fish species (Boxshall, 1998). Antimora rostrata Günther, 1878 (Gadiformes: Moridae) is recorded as a host for Lophoura tetraphylla Ho, 1985 at Northwest Atlantic Ocean (Hogans, 1986) and inhabit Antarctic waters but no specimens examined in our study were infested by L. szidati.

It is hard to evaluate the influence of fishing gear features on sampling and ultimately on the calculated indices of infestation. Bottom longline has very high level of selectivity (Petrov et al., 2014) and in Antarctic conditions only limited number of species could be caught using it and furthermore by-catch species make up no more than $5-10 \%$ by weight. On one hand, in comparison with trawl, the trawl allows better survey of the fish fauna of a particular location both in terms of species diversity and size composition. On the other hand, longline fishing allows examination of specimens of quite variable sizes. Disadvantage in using longline fishing as a source of specimens in the Antarctic also lies in the fact that fishing at depths less than $550 \mathrm{~m}$ is prohibited by the Conservation Mea- sures of the Commission for the Conservation of Marine Living Resources (CCAMLR) in order to preserve the Antarctic fauna. But most of these depths fall on shelf where deep-water fishes like Macrourus spp. are never caught, so for the present study longline works fine.

Macrourus holotrachys, which was the first recorded host of L. szidati (Stadler, 1978) from South Orkney Islands and South Sandwich Islands surprisingly showed no infestation. Unfortunately, there are no published data on the prevalence of $L$. szidati infestation on $M$. holotrachys for comparison. M. caml is recorded as a host for the first time. Despite the absence of data from the Kerguelen Islands, Prince Edward Islands and Crozet Islands slopes, it seems that the same as most endemics of the Antarctic geographical distribution of L. szidati is limited by the Antarctic Convergence. Depth distribution is related with host's features, maximal recorded depth $-2300 \mathrm{~m}$.

\section{ACKNOWLEDGEMENTS}

Author wish to thank Dr. Sergey G. Sokolov (The Center of Parasitology of A.N. Severtsov Institute of Ecology and Evolution, RAS) for helping in text preparation and to Dr. Harry Palm (Rostock University, Germany) and Dr. Vladimir Laptihovsky (Centre for Environment, Fisheries and Aquaculture Science, UK) for inspiration to prepare the present study. The work was supported by Russian Fund for Basic Research, grant \# 14-04-3195 and \#15-0402645.

\section{References}

Boxshall G.A. 1998. Host specificity in copepod parasites of deep-sea fishes // Journal of Marine Systems. Vol.15. No.1-4. P.215-223.

Brown J., Brickle P., Scott B. E. 2013. The parasite fauna of the Patagonian toothfish Dissostichus eleginoides off the Falkland Islands // Journal of Helminthology. Vol.87. No.4. P.501-509.

Cohen D.M., Inada.T., Iwamoto T., Scialabba N. 1990. FAO species catalogue. Vol.10. Gadiform fishes of the world (Order Gadiformes). An annotated and illustrated catalogue of cods, hakes, grenadiers and other gadiform fishes known to date // FAO Fisheries Synopsis. Vol.125. No.10. 442 p.

Gon O., Heemstra P.C. (eds.). 1990. Fishes of the Southern 
Ocean. Grahamstown: JLB Smith Institute of Ichthyology. $462 \mathrm{p}$.

Hogans W.E. 1986. The appendages of Lophoura tetraphylla Ho, 1985 (Copepoda: Sphyriidae) a parasite of Antimora rostrata in deep waters of the northwest Atlantic Ocean // Proceedings of the Nova Scotian Institute of Science. Vol.36. No.3/4. P.127-130.

Klimpel S., Busch M.W., Kuhn T., Rohde A., Palm H.W. 2010. The Anisakis simplex complex off the South Shetland Islands (Antarctica): endemic populations versus introduction through migratory hosts // Marine Ecology Progress Series. Vol.403. P.1-11.

McMillan P., Iwamoto T., Stewart A., Smith P.J. 2012. A new species of grenadier, genus Macrourus (Teleostei, Gadiformes, Macrouridae) from the southern hemisphere and a revision of the genus // Zootaxa. Vol.3165. P.1-24.

Miller R.G. 1993. History and atlas of the fishes of the Antarctic Ocean. Carson City: Foresta Institute for Ocean and Mountain Studies. 792 p.

Mugue N.S., Petrov A.F., Zelenina D.A., Gordeev I.I., Sergeev A.A. 2014. Low genetic diversity and temporal stability in the Antarctic toothfish (Dissostichus mawsoni) from near-continental seas of Antarctica // CCAMLR Science. Vol.21. P.1-10.

Petrov A.F., Shust K.V., Piyanova S.V., Uryupova E.F., Gordeev I.I., Sytov A.M., Demina N.S. 2014. [Guidelines for collection and processing of fishery and biological data on aquatic bioresources of the Antarctica to the Russian scientific observers in the CCAMLR area]. VNIRO. Moscow. 106 p. [in Russian]

Rintoul S., Hughes C., Olbers D. 2001. The Antarctic Circumpolar Current System BT - Ocean Circulation and Climate // Ocean Circulation and Climate. P.271301.

Sala A., Azzali M., Russo A. 2002. Krill of the Ross Sea: distribution, abundance and demography of Euphausia superba and Euphausia crystallorophias during the Italian Antarctic Expedition (January-February 2000) // Scientia Marina. Vol.66. No.22. P.123-133.

Shust K.V. 1998. [Fishes and fishery resources of the Antarctic]. VNIRO. Moscow. 161 p. [in Russian]

Siegel V., Reiss C.S., Dietrich K.S., Haraldsson M., Rohardt G. 2013. Distribution and abundance of Antarctic krill (Euphausia superba) along the Antarctic Peninsula // Deep Sea Research Part I: Oceanographic Research Papers. Vol.77. P.63-74.

Sokolov S.G., Gordeev I.I. 2013. New data on trematodes (Plathelminthes, Trematoda) of fishes in the Ross Sea (Antarctic) // Invertebrate Zoology. Vol.10. No.2. P.255-267.

Sokolov S.G., Gordeev I.I. 2015. [New data on trematodes of the Antarctic fishes] // Parazitologiya. Vol.49. No.1. P.12-27 [in Russian]

Smith P.J., Steinke D., McMillan P.J., Stewart A.L., McVeagh S.M., Diaz De Astarloa J.M., Welsford D., Ward R.D. 2011. DNA barcoding highlights a cryptic species of grenadier Macrourus in the Southern Ocean // Journal of Fish Biology. Vol.78. No.1. P.355-365.

Stadler T. 1978. Contribucion al conocimiento de los parasitos de la fauna Antarctica. Parte II. Lophoura szidati n. sp. parásito de Macrourus holotrachys Gunther (Crustacea, Sphyriidae en Pisces, Macrouridae) // Contrib. Inst. Antarct. Argent. Vol.230. P.113.

Walter T., Boxshall G. 2015. World of Copepods database. Accessed through: World Register of Marine Species at http://www.marinespecies.org/aphia.php? $\mathrm{p}=$ taxdetails \&id=135654 on 2015-05-09

Walter T., Palm H.W., Piepiorka S., Rückert S. 2002. Parasites of the Antarctic rattail Macrourus whitsoni Regan, 1913 (Macrouridae, Gadiformes) // Polar Biology. Vol.25. No.9. P.633-640.

Responsible editor N.M. Biserova 